\title{
ANKARA MUSİKİ MUALLIM MEKTEBİ MAMAK BELEDİYESİ KONSERVATUVAR BİNASI VE GÜRÜLTÜ KONTROL ANALIZí
}

\author{
Füsun DEMIREL*, Zuhal ÖZÇETİN** \\ *Mimarlık Bölümü, Mimarlık Fakültesi, Gazi Üni., Ankara/Türkiye \\ **Mimarlık Bölümü, Mühendislik-Mimarlık Fak., Bozok Üni., Yozgat/Türkiye \\ fusund@gazi.edu.tr, zuhal.ozcetin@bozok.edu.tr
}

(Geliş/Received: 15.05.2014; Kabul/Accepted: 09.10.2014)

ÖZET

\begin{abstract}
Eğitim binaları içinde özellikli bir yer tutan konservatuvar binalarında eğitim ve öğretimin verimli olabilmesi için uygun akustik koşulların sağlanması gerekmektedir. Bu düşünceden hareketle çalışmada; Ankara Musiki Muallim Mektebi Mamak Belediyesi Konservatuvar binası örneklem olarak seçilerek, çalışma odalarında konuşma seviyesi, arka plan gürültü düzeyi, uygun mekân boyutları, yapı bileşenlerinde sağlanması gereken ses yalıtım değerleri, reverberasyon süresi ve konuşmanın anlaşlabilirliği gibi parametreler araştırılmıştır. $\mathrm{Bu}$ bağlamda Ankara Musiki Muallim Mektebi Mamak Belediyesi Konservatuvar binasına ait yapı elemanlarının ses geçiş kayıpları; Insul 6.4 simülasyon programı aracıllğı ile ortaya konulmuş ardından binada çevresel gürültü düzeyi, arka plan gürültü düzeyi ve yapı elemanlarının ses geçiş kaybı ölçümleri yapılmıştır. Elde edilen sonuçlar; simülasyon programı sonuçları ile karşılaştırılarak değerlendirmeleri yapılmış ve uygun olmayan durumlar için öneriler geliştirilmiştir.
\end{abstract}

Anahtar Kelimeler: Gürültü Kontrolü, Konservatuvar Binaları, Ankara Musiki Muallim Mektebi.

\section{ANKARA MUSIKI MUALLIM MEKTEBI MAMAK MUNICIPALITY CONSERVATORY BUILDING AND NOISE CONTROL ANALYSIS}

\begin{abstract}
Conservatory buildings, which have a special role among other educational buildings, should have appropriate acoustic conditions for an effective education and teaching. Based on this view, choosing Ankara Musiki Muallim Mektebi Mamak Municipality Conservatory Building as a sample, this study analyzed parameters such as speaking rate, background noise level, suitable spatial dimensions, sound insulation values that should be met in construction components, reverberation time and speech intelligibility. In this context, Insul 6.4 simulation program was used to determine sound transmission losses of construction elements of Ankara Musiki Muallim Mektebi Mamak Municipality Conservatory Building. Environmental noise level, background noise level and sound transmission loss of construction elements were measured. The results obtained were compared to the results of the simulation program; the results were evaluated and suggestions were made for inappropriate conditions.
\end{abstract}

Key Words: Noise Control, Conservatory Buildings, Ankara Musiki Muallim Mektebi.

\section{GÍRIŞ (INTRODUCTION)}

İşitsel açıdan konforlu bir çevre oluşturmak için istenmeyen ses olarak kabul edilen gürültü, tasarım aşamasında yapıdan uzaklaştırılmalı ya da denetim altına alınmalıdır. Bunun için öncelikle gürültü koşullarının ölçüm ve simülasyon yöntemleri ile belirlenmesi ve bunlara bağlı olarak gürültü kontrolü sağlanarak mekân içindeki sesin homojen olarak dağılması sağlanmalıdır $[1,2,3]$. Bu bilgiler ışığında sesle ilgilenen insanları yetiştirmeye yönelik olarak kullanılan konservatuvar binalarında eğitim ve öğretimin verimli olabilmesi için hacim içerisinde ihtiyaç duyulan akustik koşulların sağlanması ve arka plan gürültü düzeyinin denetlenmesi gerekmektedir.

Bu bağlamda çalışmanın amacı; müzik eğitimi verilen binalarda akustik konforun sağlanması gerekliliği düşüncesinden hareketle, Ankara'nın önemli tarihi binalarından Musiki Muallim Mektebi Mamak 
Belediyesi Konservatuvar binasına ait çalışma odalarının (sınıfların) akustik performansının değerlendirilmesidir. Bu amaç doğrultusunda gürültü kontrolü ile ilgili ulusal ve uluslararası mevzuatlar konservatuvar binaları açısından incelenerek, performans kriterleri ortaya konmuş $[4,5,6]$ ve örneklem olarak seçilen Ankara Musiki Muallim Mektebi Mamak Belediyesi Konservatuvar binasının; Insul 6.4 simülasyon programı ve yerinde yapılan akustik ölçümler aracılığı ile gürültü kontrolüne yönelik analizleri yapılmış ve değerlendirilmiştir.

\section{YÖNTEM (METHOD)}

$\mathrm{Bu}$ çalışmada, öncelikle sağlıklı karşılaştırma yapılabilmesi için Insul 6.4 simülasyon programının güvenilirliği sınanmış ve güvenilirlik \%5'lik bir farkla doğrulanmıştır. Örneklem olarak seçilen Ankara Musiki Muallim Mektebi Mamak Belediyesi Konservatuvar binasına ait yapı elemanlarının ses geçiş kayıpları (ses azaltma indeksi değerleri); aynı özelliklere sahip iki sınıfta Insul 6.4 simülasyon programı ile ortaya konup, ardından da sinıflarda çevresel gürültü düzeyi, arka plan gürültü düzeyi ve yapı elemanlarının ses geçiş kaybı ölçümleri yapılmıştır. Elde edilen sonuçlar; simülasyon programı ve oluşturulan performans kriterleriyle karşılaştırılarak değerlendirilmiş, uygun olmayan durumlar için öneriler geliştirilmiştir.

\section{ANKARA MUSÍKI MUALLIM MEKTEBİ MAMAK BELEDIYESİ KONSERVATUVAR BINASININ GÜRÜLTÜ KONTROL ANALIZİ (ANKARA MUSIKİ MUALLIM MEKTEBI MAMAK MUNICIPALITY CONSERVATORY BUILDING NOISE CONTROL ANALYSIS)}

Ankara Musiki Muallim Mektebi, 1928 y1lında Avusturya kökenli İsviçreli mimar Ernest Arnold EGLI tarafindan tasarlanan ve 1938 yılında eklenen yeni mekânlarla genişleyerek Devlet Konservatuvarı olmuştur.

3.1. Bina ve Çalışma Odalarıyla İlgili Genel Bilgiler (General Information about the Building and Study Rooms)

Alt katta sinifların, üst katta yatakhanelerin bulunduğu avlulu 2 katlı konservatuvar binasının zemin katında; müzik eğitimi için düzenlenen sınıflar, konser-tiyatro salonu, merdiven ve revaklı ana giriş yer almaktadır. İkinci katta revir, yatakhanenin bir bölümü ve okuma odası, bodrumda yemekhane ve mutfak yer almaktadır. Avlu; üç yönde revaklarla çevrilmiştir (Şekil 1-2) [7].

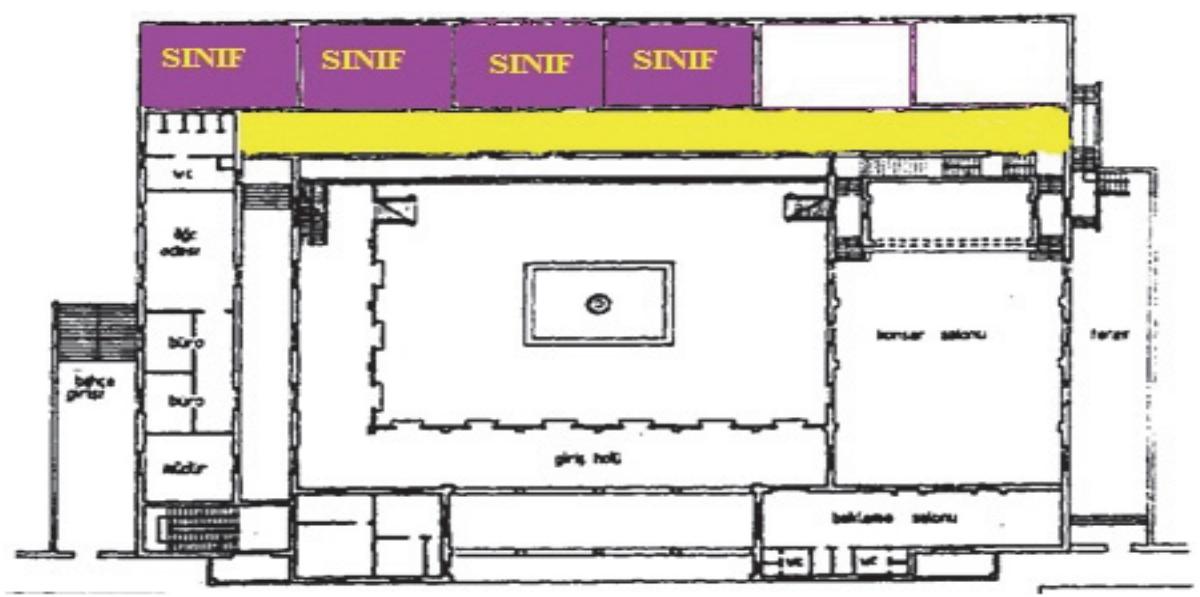

Şekil 1. Musiki Muallim Mektebi, Ankara, 1927-29 Zemin Kat Planı (Musiki Muallim Mektebi, Ankara, 1927-29, Ground Floor Plan) [4,7]

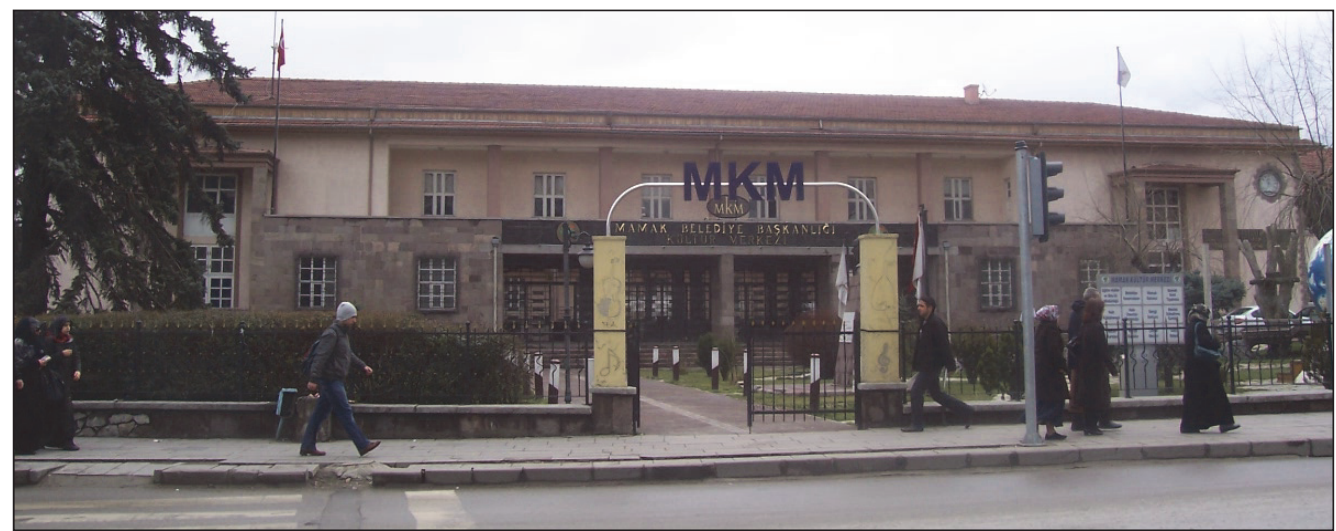

Şekil 2. Ankara Musiki Muallim Mektebi Mamak Belediyesi Konservatuvar Binası'nın Görünüşü (Appearance of Ankara Musiki Muallim Mektebi Mamak Municipality Conservatory Building) 
Günümüzde Mamak Kültür Merkezi olarak kullanılan ve doğusundan tren yolu geçen binanın; $12.400 \mathrm{~m}^{2}$ kapalı alana sahip olup, 289 kişilik tiyatro ve konser salonu, 100 kişilik tiyatro salonu, $500 \mathrm{~m}^{2}$ 'lik sergi salonu, $4000 \mathrm{~m}^{2}$ 'lik eğitim salonu, $600 \mathrm{~m}^{2}$ 'lik halk kütüphanesi, $150 \mathrm{~m}^{2}$ 'lik çocuk meclisi salonu, 1000 $\mathrm{m}^{2}$ 'lik restaurant ve $750 \mathrm{~m}^{2}$ 'lik kafesi bulunmaktadır [7].

\section{2. Çalışma Odalarını Çevreleyen Yapı} Elemanlarının Ses Yalıtım Performansının Simülasyon Yöntemi ile Analizi (Analysis of Sound Insulation Performance of the Construction Elements that Surround Study Rooms with Simulation Method)

Bu çalışmada; öncelikle çalıșma odalarının mevcut durumu için kabul edilen performans kriterleri belirlenmiş (Tablo 1), kullanılacak olan simülasyon programının güvenilirliği sorgulanmış ve bu amaçla Insul 6.4 simülasyon programı ile elde edilen veriler literatür bilgileri ile karşılaştırılmıştır (Tablo 2).

Tablo 2'de görüldüğü üzere literatür bilgileri ile Insul 6.4 simülasyon programı arasında en fazla $3 \mathrm{~dB}$ ile \%5'lik bir fark olduğu saptanmıştır. Söz konusu sonuçların güven aralığında yer almasından dolayı Insul 6.4 simülasyon programı bu çalışmada güvenle kullanılmıştır. $\mathrm{Bu}$ bağlamda; çalıșma odalarını çevreleyen yapı elemanları Insul 6.4 simülasyon programıyla analiz edilerek, belirlenen ses geçiş kayıpları (ses azaltma indeksi değerleri), Tablo 3 'te verilmiştir.

\section{3. Çalışma odalarının gürültü kontrol ölçüm yöntemi ile analizi (Analysis of Study Rooms with Noise Control Measurement Method)}

Çalışmanın amacı doğrultusunda, gürültü kontrolüne ilişkin değişkenlerden sırasıyla çevresel gürültü düzeyi, arka plan gürültü düzeyi ve yapı elemanlarının ses azaltma indeksi değerleri ölçülmüştür.

Çevresel Gürültü Düzeyi Öçümleri:

Ölçümler; TS ISO 1996-2: Mart 2009 standardına uygun olarak Reten Electronic RS104 SLM ses seviyesi ölçer ile gerçekleştirilmiştir. Ölçümlere başlanmadan önce ses düzeyi ölçer kalibre edilmiştir. Zeminden $1,50 \mathrm{~m}$ yükseklikte gerçekleştirilen ölçümlerde rüzgârlık kullanılmıştır. Ölçüm sırasındaki hava koşulları aşağıda belirtildiği gibidir. Hava sicaklığı: $19,3^{\circ} \mathrm{C}$, Nem: \% 33,5, Basınç: $915 \mathrm{hPa}$, Rüzgâr hızı ve yönü: 0,8 m/sn, Kuzey, Yağış: Yok.

Ölçümler; belirlenen Alıcı 1, Alıcı 2 ve Alıcı 3 noktaları için 2 dakikalık sürelerle beş kez tekrarlanarak ortalamalar alınmıştır (Şekil 3-4 ve Ek$1)$.

Tablo 1. Ankara Musiki Muallim Mektebi Mamak Belediyesi Konservatuvar Binası Çalışma Odalarının Mevcut Durumu İçin Kabul Edilen Performans Kriterleri (Performance Criteria Accepted for the Current ( Situation of the Study Rooms in Ankara Musiki Muallim Mektebi Mamak Municipality Conservatory Building) $[4,5,6]$

\begin{tabular}{|c|c|c|}
\hline & Parametreler & Kabul Edilen Performans Kriterleri \\
\hline \multirow[b]{2}{*}{$\begin{array}{l}\text { Arka plan } \\
\text { gürültü düzeyi }\end{array}$} & \begin{tabular}{|l|l|l|l|} 
Sinır \\
\end{tabular} & Müzik sınıfları: 35 dBA $(\sim \mathrm{NC} 25)[11,12]$ \\
\hline & Büyük hacimler & $\begin{array}{l}\text { - Temel öğrenme mekânı }>283 \mathrm{~m}^{3} \text { ve } \leq 566 \mathrm{~m}^{3}: 35 \mathrm{dBA} \text { [13] } \\
\text { - Temel öğrenme mekânı }>566 \mathrm{~m}^{3} \text { ve tüm yardımc öğrenme mekânı: } 40 \mathrm{dBA} \text { [13] }\end{array}$ \\
\hline \multirow{3}{*}{$\begin{array}{l}\text { Mekânın } \\
\text { boyutları }\end{array}$} & Müzik odaları & $\begin{array}{l}\text { - Öğrenim odası: } 85 \mathrm{~m}^{2}[11] \\
\text { - Çalışma odası: } 20 \mathrm{~m}^{2}[11] \\
\text { - Pratik yapılan grup odaları: } 8 \mathrm{~m}^{2}[11]\end{array}$ \\
\hline & Mekânın geometrisi & $\begin{array}{l}\text { Mekânın en/yükseklik/boy oranı 1.25:1:1.6 oranı en ideal oran olarak kabul } \\
\text { edilmektedir [11]. }\end{array}$ \\
\hline & Mekânın toplam hava hacmi & $\begin{array}{l}\text { - Yüksek sesli enstrümanlarla kişisel derslerin yapıldığı odalar: } 40 \mathrm{~m}^{3}[14] \\
\text { - Orkestra prova odaları ve kişisel çalış̧a odaları: En az 20-30 } \mathrm{m}^{3}[14] \\
\text { - Koro prova odaları: } 10-15 \mathrm{~m}^{3}[14]\end{array}$ \\
\hline \multirow{3}{*}{$\begin{array}{l}\text { Yapı } \\
\text { bileşenlerinde } \\
\text { sağlanması } \\
\text { gereken ses } \\
\text { yalıtım } \\
\text { değerleri }\end{array}$} & $\begin{array}{l}\text { Binanın, dış duvar ve çatı gibi } \\
\text { yapı bileşenlerinde sağlanması } \\
\text { gereken ses yalıtımı (Sınıflar } \\
\text { için) }\end{array}$ & $\begin{array}{l}\text { - Çevresel gürülttü düzeyi 56-60 dBA arasında olan yerlerde: Rw,res : } 30 \mathrm{~dB} \text { [15]. } \\
\text { - Çevresel gürültü düzeyi } 55 \text { dBA' ya kadar olan yerlerde: Rw,res : } 30 \mathrm{~dB} \text { [15]. }\end{array}$ \\
\hline & $\begin{array}{l}\text { Mekânlar arasındaki yapı } \\
\text { elemanlarında havada yayılan } \\
\text { ses yalıtımı }\end{array}$ & $\begin{array}{l}\text { - Sinıflar ve koridorlar arasındaki kapılar: Rw: } 32 \mathrm{~dB} \text { [11] } \\
\text { - Sinıflar ve merdivenler arasındaki duvarlar: Rw: } 52 \mathrm{~dB} \text { [11] } \\
\text { - Sinıflar ve jimnastik, müzik odaları, atölye gibi odalar arasındaki duvarlar: Rw: } \\
55 \mathrm{~dB} \text { [15] } \\
\text { - Sinıflarda tavanlar ve döşemeler: Rw: 55dB [15] }\end{array}$ \\
\hline & $\begin{array}{l}\text { Döşemelerde katılarda yayılan } \\
\text { ses yalıtımı }\end{array}$ & $\begin{array}{l}\text { - Sinıflar arasındaki döşemeler Ln,w : } 53 \mathrm{~dB}[15] \\
\text { - Sinıflar ve jimnastik, müzik odaları, atölye gibi odalar arasındaki döşemeler Ln,w } \\
: 46 \mathrm{~dB}[15]\end{array}$ \\
\hline \multirow{2}{*}{$\begin{array}{l}\text { Reverberasyon } \\
\text { süresi }\end{array}$} & & $\begin{array}{l}\text { - } \mathrm{V}<283 \mathrm{~m}^{3} \text { sinuflar için } \mathrm{T}=0,6 \mathrm{sn}[16,17] \\
\text { - } 283 \mathrm{~m}^{3}<\mathrm{V} \leq 566 \mathrm{~m}^{3} \text { sinıflar için } \mathrm{T}=0,7 \mathrm{sn}[16,17]\end{array}$ \\
\hline & $\begin{array}{l}\text { Öğrenme ve çalışma } \\
\text { mekânlarında reverberasyon } \\
\text { süresi }\end{array}$ & Müzik sınıfları T<1,0 sn [11] \\
\hline $\begin{array}{l}\text { Konuşmanın } \\
\text { anlaşılabilirliği }\end{array}$ & & Konuşma iletim indeksi (STI) >0,60 [11] \\
\hline
\end{tabular}


Tablo 2. Insul 6.4 Simülasyon Programının Güvenilirliği (Reliability of Insul 6.4 Simulation Program) [4]

\begin{tabular}{|c|c|c|c|c|c|}
\hline Kaynaklar & $\begin{array}{l}\text { Yapı Bilesseninin } \\
\text { Detayları }\end{array}$ & $\begin{array}{l}\text { Yapı Bileşenlerinin } \\
\text { Malzeme Bilgileri }\end{array}$ & $\begin{array}{c}\text { Laboratuvar } \\
\text { Koşullarındaki } \\
\text { Ölçüm Sonuçları } \\
\text { (dB) } \\
\end{array}$ & $\begin{array}{c}\text { Insul } 6.4 \\
\text { Simülasyon } \\
\text { Programı (dB) }\end{array}$ & $\begin{array}{l}\text { Ölçüm ve Simülasyon } \\
\text { Yöntemleri } \\
\text { Arasındaki Fark (dB) }\end{array}$ \\
\hline \multirow{3}{*}{$\begin{array}{l}\text { W.Cavanaugh, } \\
\text { J.Wilkes [8] }\end{array}$} & & $\begin{array}{l}12,5 \mathrm{~mm} \text { alçı sıva }+150 \mathrm{~mm} \\
\text { betonarme duvar }+12,5 \mathrm{~mm} \\
\text { alçı sıva }\end{array}$ & 53 & 56 & 3 \\
\hline & & $\begin{array}{l}\text { 12,5mm alçı pano+ } \\
100 \mathrm{~mm} \text { boşluk (ahşap } \\
\text { taşıı1c1 aralığı } 400 \mathrm{~mm}) \\
+12,5 \mathrm{~mm} \text { alçı pano }\end{array}$ & 32 & 35 & 3 \\
\hline & & $\begin{array}{l}15,9 \mathrm{~mm} \text { alçı pano }+65 \mathrm{~mm} \\
\text { boşluk }(\text { metal taşı1.c1 } \\
\text { aralığı } 600 \mathrm{~mm})+15,9 \mathrm{~mm} \\
\text { alçı pano }\end{array}$ & 36 & 36 & - \\
\hline \multirow{3}{*}{$\begin{array}{l}\text { M.David Egan } \\
\text { [9] }\end{array}$} & & $\begin{array}{l}12,5 \mathrm{~mm} \text { alçı sıva }+150 \mathrm{~mm} \\
\text { betonarme duvar }+12,5 \mathrm{~mm} \\
\text { alçı sıva }\end{array}$ & 53 & 56 & 3 \\
\hline & & $\begin{array}{l}2 \times 16 \mathrm{~mm} \text { alçı pano }+65 \mathrm{~mm} \\
\text { boşluk, içi taş yünü } \\
\text { doldurulmuş (metal } \\
\text { taşıyıcı aralığ } 600 \mathrm{~mm})+ \\
16 \mathrm{~mm} \text { alçı pano }\end{array}$ & 51 & 51 & - \\
\hline & & $\begin{array}{l}6 \mathrm{~mm} \text { cam }+50 \mathrm{~mm} \\
\text { boşluk }+4 \mathrm{~mm} \text { cam }\end{array}$ & 39 & 40 & 1 \\
\hline $\begin{array}{l}\text { M.Mehta, } \\
\text { J.Rocaford, } \\
\text { J.Johnson [10] }\end{array}$ & & $300 \mathrm{~mm}$ tuğla duvar & 61 & 60 & 1 \\
\hline \multirow{2}{*}{ BB93 [11] } & & $\begin{array}{l}12,5 \mathrm{~mm} \text { alçı pano }+ \\
115 \mathrm{~mm} \text { tuğla duvar }+ \\
12,5 \mathrm{~mm} \text { alçı pano }\end{array}$ & $45-50$ & 46 & 1 \\
\hline & & $\begin{array}{l}2 \times 12,5 \mathrm{~m} \text { alçı } \\
\text { pano }+150 \mathrm{~mm} \text { boşluk, içi } \\
75 \mathrm{~mm} \text { cam yünü } \\
\text { doldurulmuş (metal } \\
\text { taşı1yıc1lı) }+2 \times 12,5 \mathrm{~mm} \\
\text { alçı pano }\end{array}$ & $50-55$ & 55 & - \\
\hline
\end{tabular}


Tablo 3. Çalışma Odalarında Insul 6.4 Simülasyon Programı ile Elde Edilen Yapı Elemanlarının Ses Azaltma İndeksi Değerleri (Sound Reduction Index Values of Construction Elements in Study Rooms Obtained from Insul 6.4 Simulation Program) [4]

\begin{tabular}{|c|c|c|c|}
\hline Yapı Elemanları & $\begin{array}{c}\text { Yapı Bileşeninin Malzeme } \\
\text { Bilgileri }\end{array}$ & Yapı Bileşeninin Detayları & $\begin{array}{c}\text { Ses Azaltma İndeksi } \\
\text { Rw (C;Ctr) ve Ln,w }\left(C_{1}\right)(d B)\end{array}$ \\
\hline $\begin{array}{l}\text { Sinıflar Arasındaki } \\
\text { Duvar }\end{array}$ & $\begin{array}{l}25 \mathrm{~mm} \text { sıva }+90 \mathrm{~mm} \text { tuğla } \\
\text { duvar+ } \\
50 \mathrm{~mm} \text { camyünü }+90 \mathrm{~mm} \text { tuğla } \\
\text { duvar+ } 25 \mathrm{~mm} \text { sıva }\end{array}$ & & $R w=56(-1 ;-3)$ \\
\hline $\begin{array}{l}\text { Sinıf ve Koridor } \\
\text { Arasındaki Duvar } \\
\text { (Bileşik Cidar) }\end{array}$ & $\begin{array}{l}25 \mathrm{~mm} \text { sıva }+90 \mathrm{~mm} \text { tuğla } \\
\text { duvar+ } \\
50 \mathrm{~mm} \text { camyünü+ }+90 \mathrm{~mm} \text { tuğla } \\
\text { duvar }+25 \mathrm{~mm} \text { siva }+ \text { kapı }\end{array}$ & & $\mathrm{Rw}=\mathbf{3 0}(0 ; 1)$ \\
\hline \multirow[t]{2}{*}{$\begin{array}{l}\text { Sinıfların Tavan } \\
\text { Döşemesi }\end{array}$} & \multirow[t]{2}{*}{$\begin{array}{l}2,6 \mathrm{~mm} \text { vinil döşeme kaplaması } \\
+150 \mathrm{~mm} \text { betonarme döşeme }+ \\
1500 \mathrm{~mm} \text { boşluk }+Z \text { profil } \\
\text { taşıyıc }+16 \mathrm{~mm} \text { delikli taşyünü } \\
\text { asma tavan }\end{array}$} & & $R w=62(-1 ;-5)$ \\
\hline & & & $\operatorname{Ln}, w=58(-7)$ \\
\hline \multirow{2}{*}{$\begin{array}{l}\text { Sınıfların Zemin } \\
\text { Döşemesi }\end{array}$} & \multirow{2}{*}{$\begin{array}{l}2,6 \mathrm{~mm} \text { vinil döşeme } \\
\text { kaplaması }+150 \mathrm{~mm} \text { betonarme } \\
\text { döşeme }+250 \mathrm{~mm} \text { boşluk }+Z \\
\text { profil taşı1yı }+16 \mathrm{~mm} \text { delikli } \\
\text { taşyünü asma tavan }\end{array}$} & & $R w=62(-2 ;-5)$ \\
\hline & & & $\operatorname{Ln}, w=59(-5)$ \\
\hline
\end{tabular}

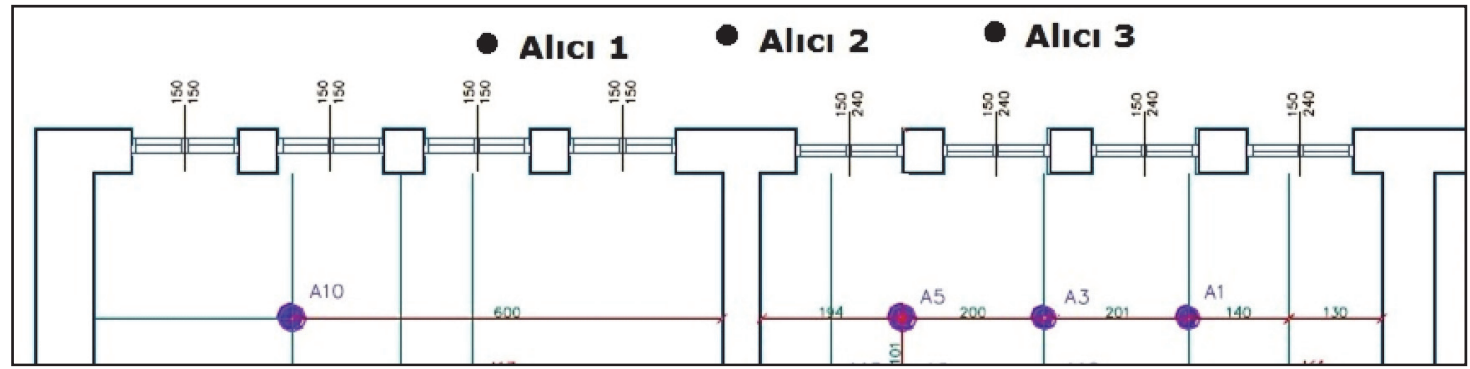

Şekil 3. Alıcı 1, Alıcı 2 ve Alıc1 3 noktaları (Receiver 1, Receiver 2 and Receiver 3 points)

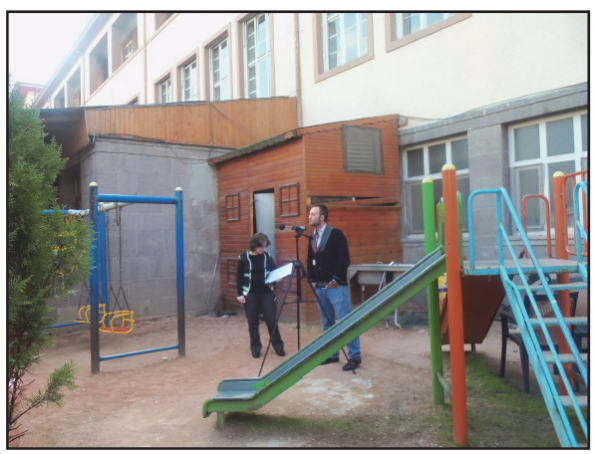

(a)

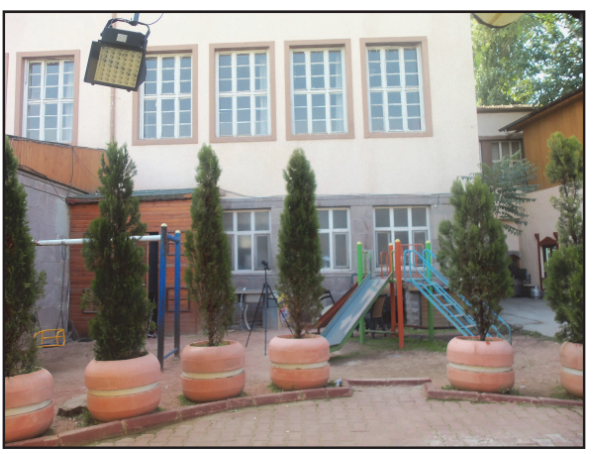

(b)

Şekil 4. (a) (b) Yapılan Ölçümlerden Fotoğraflar (Photographs of Measurements) 
Arka plan gürültü düzeyi ölçümleri:

Çalışma odaları için arka plan gürültü düzeyi ölçümleri TS ISO 1996-2: Mart 2009 [18] standardına uygun olarak Reten Electronic RS104 SLM ses seviyesi ölçer ile gerçekleştirilmiştir. Ölçümler; sınıfın boyutuna ve mekânsal düzenlemesine bağlı olarak belirlenen 6 adet (A1,A2,A3,A4,A5,A6) ölçüm noktasında yapılmıştır (Şekil 5-6). İlk alıcı, döşemeden 1,30 m yükseklikte, diş cephe duvarından 2,00 m ve yazı tahtasının bulunduğu duvardan 4,70 m uzaklıkta konumlandırılmıştır. Diğer alıcılar, yine 1,30 m yüksekliğe ayarlanarak arkadan öne ve sağdan sola 2 'er $\mathrm{m}$ ara ile yerleştirilmiştir.

Ölçümlere başlamadan önce mikrofonlar kalibre edilmiştir. Daha sonra ölçümler, belirlenen her bir alıcı noktası için 1/3 oktav bant frekanslarına bağlı olarak 16 saniyelik sürelerle üçer kez tekrar edilerek ortalamaları alınmıştır (Ek-2). Ölçülen arka plan gürültü düzeyinin $125-2000 \mathrm{~Hz}$ aralığında; literatüre uygun olarak NC-25 eğrisinin altında olduğu, yüksek frekanslarda ise eğrinin dışına çıktığı görülmüştür (Şekil 7).

Yapı elemanlarının ses geçiş kaybı ölçümleri:

Çalışma odalarını çevreleyen yapı elemanları ve yapılar için TS EN ISO 16283-1:2014 [19] standardına uygun olarak ses azaltma indeksi ölçümleri; mekân/alan boyutlarına, mekânsal düzenlemeye ve mekânın bitişik mekânlarla olan ilişkisine bağlı olarak belirlenen kaynak ve alıcı noktalarında yapılmıştır. Ölçümler; iç duvarlar için sınıf ile bitişik mekânlar (sınıf-sınıf ve sınıf-koridor) arasında gerçekleştirilmiştir. Dış duvarda yapılması planlanan ölçümler, cephede yer alan sundurmadan dolayı yapılamamıştır. Ölçümlere başlanmadan önce mikrofonlar kalibre edilmiştir. Daha sonra ölçümler, belirlenen her bir alıcı noktası için frekanslara bağlı olarak 12 yüzlü ses kaynağından 16 sn'lik beyaz gürültü verilmesi ile üçer kez tekrar edilmiş, kaynak ve algılama mekânlarındaki eşdeğer sürekli ses basınç seviyeleri (Leq) ölçülmüştür. Ardından ölçüm değerlerinin ortalamaları alınarak, yapı elemanlarının havada yayılan ses karşısındaki performansını belirlemek üzere kullanılan, "Ses Azaltma İndeksi”;

$\mathrm{RW}=\mathrm{L}_{1}-\mathrm{L}_{2}+10 \log \mathrm{S} / \mathrm{A}$,

formülü ile hesaplanmıștır. Burada;

$\mathrm{Rw}=$ ses azaltma indeksi $(\mathrm{dB})$,

$\mathrm{L}_{1}=$ kaynak odasındaki ortalama ses basınç seviyesi $(\mathrm{dB})$,

$\mathrm{L}_{2}=$ algılama odasındaki ortalama ses basınç seviyesi $(\mathrm{dB})$,

$\mathrm{S}=$ ara duvarın - döşemenin alanı $\left(\mathrm{m}^{2}\right)$,

$\mathrm{A}=$ algılama odasındaki eş değer absorpsiyon alanını (Sabin, $\mathrm{m}^{2}$ ), göstermektedir.

Eş değer absorpsiyon alanı aşağıdaki formülle hesaplanmıştır.

$\mathrm{A}=\frac{0,16 \mathrm{~V}}{T}$
Burada;

A: Algılama odasındaki eşdeğer ses absorpsiyon alanı (ses yutucu yüzey alanı, $\mathrm{m}^{2}$ )

V: Algilama odasinın hacmi, $\mathrm{m}^{3}$

T: Algılama odasındaki reverberasyon süresini, sn ifade etmektedir.

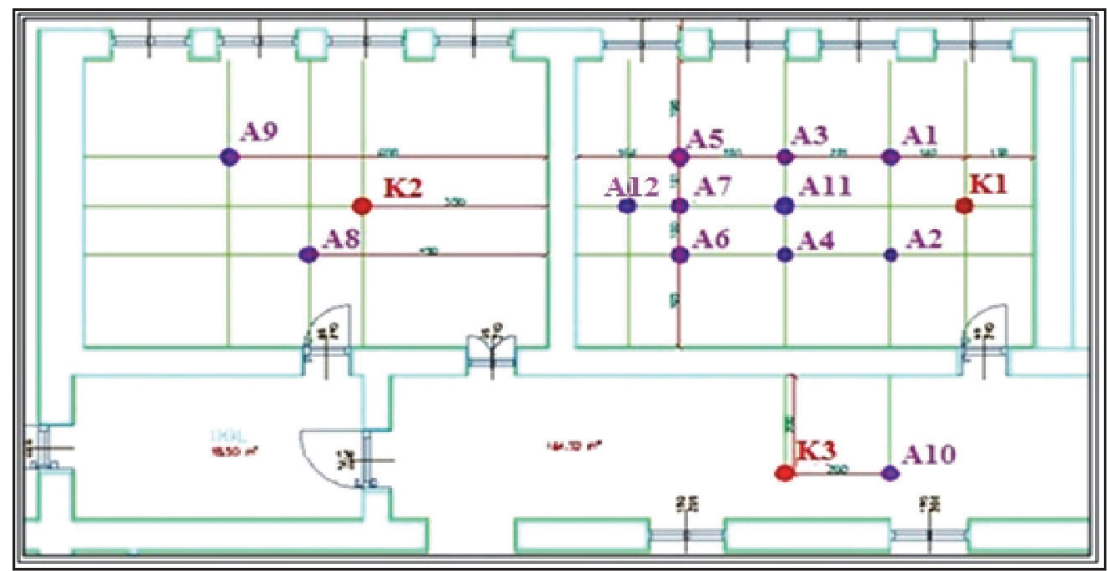

Şekil 5. Yapılan ölçümler için Kaynak ve Alıcı Noktaları (Source and Receiver Points for the Measurements)

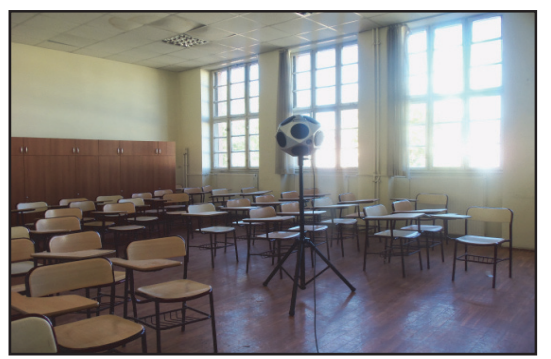

(a)

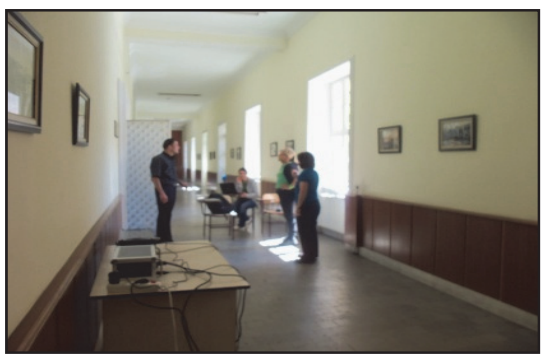

(b)

Şekil 6. (a) (b) Yapılan Ölçümlerden Fotoğraflar (Photographs of Measurements) 


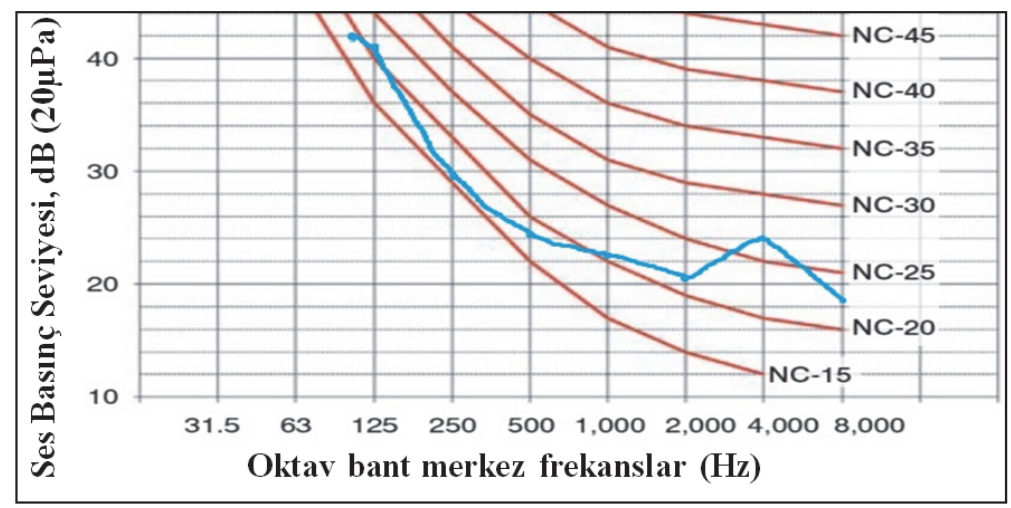

Gürültüi kriteri eğrileri (NC)

Şekil 7. Yapılan Ölçümler Sonucunda Arka Plan Gürültü Düzeyi Grafiği (Background Noise Level Graphic in Results Measurement)

Sinıflarda algılama odasında orta frekanslardaki (500, $1000 \mathrm{~Hz}$ ortalamas1) reverberasyon süresi $\left(\mathrm{T}_{\mathrm{mid}}\right) ; 0,8$ sn olarak ölçülmüştür. Algılama odasının hacmi 179,6 $\mathrm{m}^{3}$ 'tür.

TS ISO 1996-2: Mart 2009 [18] standard doğrultusunda; iki sınıf arasındaki iç duvar için K2 ses kaynağı sabit, A6, A8, A9 ve A12 alıc1 noktalarında olmak üzere 4 noktada ölçüm alınmıştır. K2 ses kaynağı orta aks üzerinde yazı tahtasının bulunduğu duvardan $3,50 \mathrm{~m}, \mathrm{~A} 8 ; 4,50 \mathrm{~m}, \mathrm{~A} 9 ; 6,00 \mathrm{~m}$, yan duvardan ise $2,00 \mathrm{~m}$ uzaklıkta yerleştirilmiştir (Şekil 5-6). Sınıf ile koridor arasındaki iç duvar için TS ISO 1996-2: Mart 2009 standardı doğrultusunda; K3 ses kaynağ1 sabit, A10, A1 ve A4 alıc1 noktalarında olmak üzere 3 noktada ölçüm alınmıştır. $\mathrm{K} 3$ ses kaynağ1; duvardan 2,00 $\mathrm{m}$ ara ile konumlandırılmıştır (Şekil 5-6). Bu ölçme noktalarında frekanslara bağlı olarak ölçülen ortalama ses basınç seviyeleri; Ek-3 ve Ek-4'te, sınıflar arasındaki duvarın ses azaltma indeksi grafikleri; Şekil 8-a ve b'de verilmiştir.

\section{DEĞERLENDİRME (ASSESSMENT)}

$\mathrm{Bu}$ çalışma için seçilen Ankara Musiki Muallim Mektebi Mamak Belediyesi Konservatuvar binasının çalışma odalarının gürültü kontrol analizini yapmak üzere öncelikle, sınıfları çevreleyen yapı elemanlarının ses azaltma indeksi değerleri, güvenilirliği kanıtlanmış olan Insul 6.4 simülasyon programı ile ortaya konmuş, ardından sınıflarda çevresel gürültü düzeyi, arka plan gürültü düzeyi ve yapı elemanlarının ses azaltma indeksi ölçümleri ve hesaplamaları yapılmıştır. Elde edilen sonuçlar; simülasyon programı ve oluşturulan performans kriterleriyle karşılaştırılarak değerlendirilmiștir. Bu çalışma kapsamında elde edilen bulgular ve değerlendirmeleri içeren bilgiler Tablo 4'de verilmiştir.
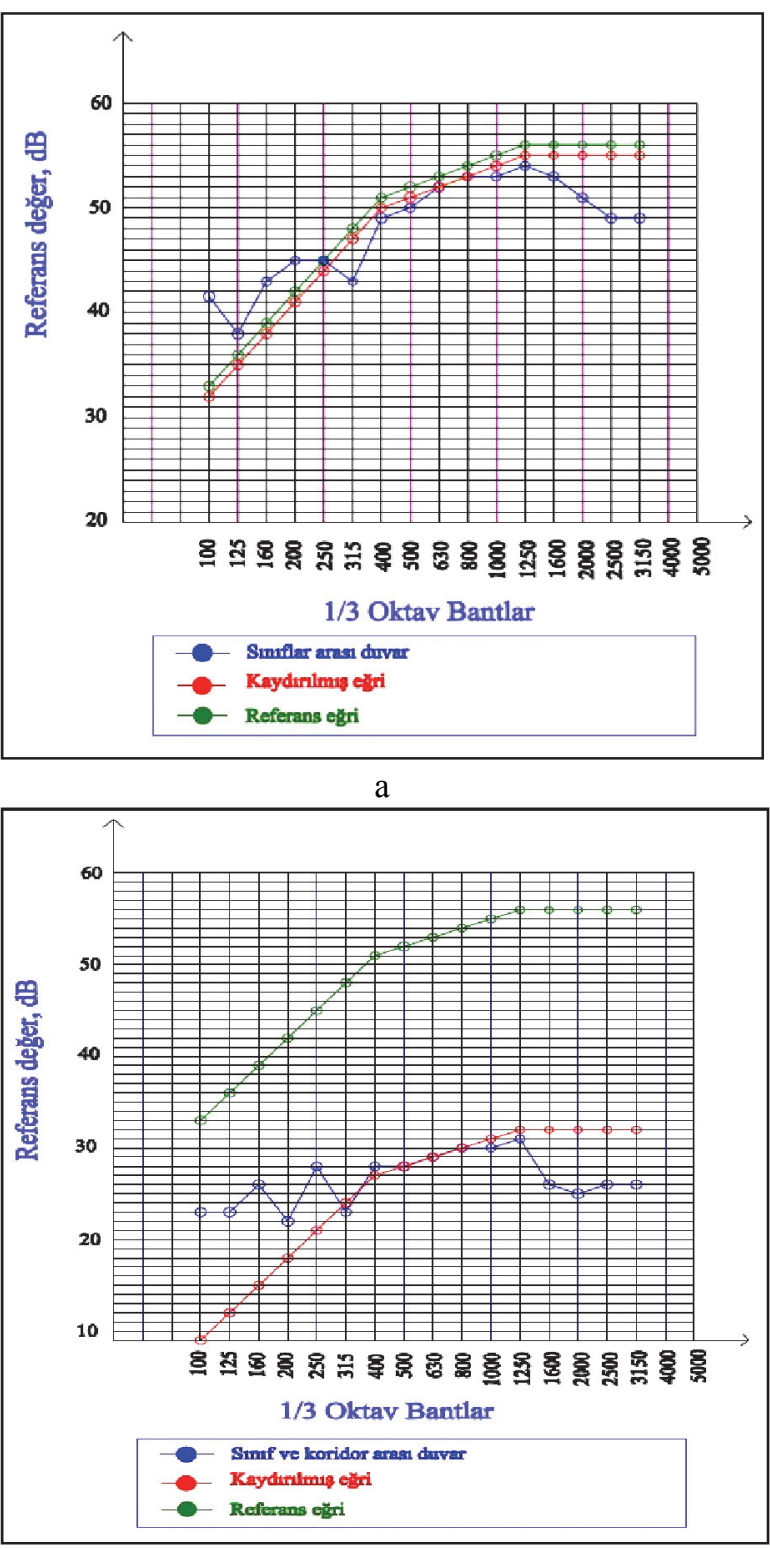
$\mathrm{b}$

Şekil 8. Yapılan Ölçümler Sonucunda a) Sınıflar Arasındaki Duvarın Ses Azaltma İndeksi Grafiği b) Sınıf ve Koridor Arası Duvarın Ses Azaltma İndeksi Grafiği (Based on the Measurements a) Sound Reduction Index Graph of the Wall between the Classrooms b) Sound Reduction Index Graph of the Wall between the Classroom and the Corridor) 
Tablo 4. Ankara Musiki Muallim Mektebi Mamak Belediyesi Konservatuvar Binası Çalışma Odalarına Yönelik Akustik Analiz (Acoustic Analysis for Study Rooms of Ankara Musiki Muallim Mektebi Mamak Municipality Conservatory Building) [4]

\begin{tabular}{|c|c|c|c|c|c|c|c|}
\hline 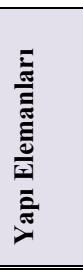 & $\begin{array}{c}\text { Yapı } \\
\text { Bileşeninin } \\
\text { Malzeme } \\
\text { Bilgileri }\end{array}$ & $\begin{array}{l}\text { Yapı } \\
\text { Bileşe- } \\
\text { ninin } \\
\text { Detayı }\end{array}$ & $\begin{array}{c}\text { Optimum } \\
\text { Değerler } \\
\text { Rw } \\
\text { (C;Ctr) ve } \\
\left.\text { Ln,w (C } \text { C }_{1}\right) \\
\text { (dB) }\end{array}$ & $\begin{array}{c}\text { Insul 6.4 } \\
\text { Simülasyon } \\
\text { Programı Ses } \\
\text { Azaltma } \\
\text { İndeksi Değeri } \\
\text { Rw }(C ; C t r) \text { ve } \\
\text { Ln,w }\left(C_{1}\right)(d B)\end{array}$ & $\begin{array}{c}\text { Yapılan } \\
\text { Ölçümler } \\
\text { Aracılığı ile } \\
\text { Hesaplanan } \\
\text { Ses Azaltma } \\
\text { İndeksi } \\
\text { Rw (C;Ctr) * } \\
\text { (dB) } \\
\end{array}$ & Değerlendirme & Öneriler \\
\hline 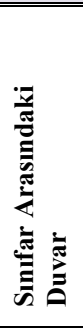 & $\begin{array}{l}25 \mathrm{~mm} \\
\text { siva+90mm } \\
\text { tuğla duvar+ } \\
50 \mathrm{~mm} \\
\text { camyünü+ } \\
90 \mathrm{~mm} \text { tuğla } \\
\text { duvar+ }+25 \mathrm{~mm} \\
\text { siva }\end{array}$ & & $\begin{array}{c}\mathrm{Rw} \\
{[15]}\end{array}$ & $R w=56(-1 ;-3)$ & $\begin{array}{c}\mathrm{Rw}=51 \\
(0 ;-2)\end{array}$ & 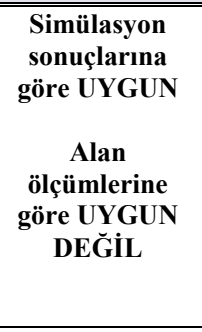 & $\begin{array}{c}\text { Yapılan } \\
\text { tadilatlardan } \\
\text { dolayı duvarda } \\
\text { bazı açılıklar } \\
\text { oluşmuştur. Bu } \\
\text { açıklıkların } \\
\text { kapatılması ile } \\
\text { olumlu sonuçlar } \\
\text { elde } \\
\text { edilebilecektir. } \\
\end{array}$ \\
\hline 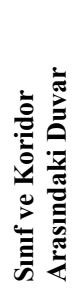 & $\begin{array}{l}25 \mathrm{~mm} \\
\text { siva+90mm } \\
\text { tuğla duvar+ } \\
50 \mathrm{~mm} \\
\text { camyünü+ } \\
90 \mathrm{~mm} \text { tuğla } \\
\text { duvar+ } 25 \mathrm{~mm} \\
\text { siva }\end{array}$ & & $\begin{array}{c}\mathrm{Rw} \\
{[15]}\end{array}$ & $R w=30(0 ; 1)$ & $\begin{array}{c}\mathrm{Rw}=28 \\
(-1 ;-1)\end{array}$ & $\begin{array}{c}\text { Simülasyon ve } \\
\text { alan } \\
\text { ölçümlerine } \\
\text { göre UYGUN } \\
\text { DEĞíL }\end{array}$ & $\begin{array}{l}\text { Kapıların ses } \\
\text { yalıtım değerleri } \\
\text { yükseltilmeli ve } \\
\text { kasa-kanat, kanat- } \\
\text { döşeme boşluğu } \\
\text { conta, keçe vb. ile } \\
\text { kapatılmalıdır. }\end{array}$ \\
\hline \multirow{2}{*}{ 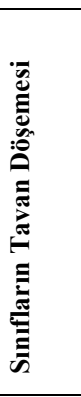 } & \multirow{2}{*}{$\begin{array}{l}2,6 \mathrm{~mm} \text { vinil } \\
\text { döşeme } \\
\text { kaplaması }+ \\
150 \mathrm{~mm} \\
\text { betonarme } \\
\text { dösseme }+ \\
1500 \mathrm{~mm} \text { boşluk } \\
+Z \text { profil } \\
\text { taşı11с1 }+16 \mathrm{~mm} \\
\text { delikli taşyünü } \\
\text { asma tavan }\end{array}$} & \multirow{2}{*}{ 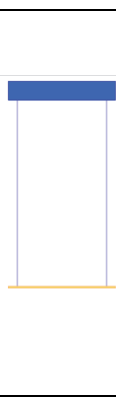 } & $\begin{array}{c}\mathrm{Rw} \\
{[15]}\end{array}$ & $R w=62(-1 ;-5)$ & \multirow{2}{*}{-} & $\begin{array}{c}\text { Simülasyon } \\
\text { sonuçlarına } \\
\text { göre UYGUN }\end{array}$ & - \\
\hline & & & $\begin{array}{c}\text { Ln,w } \leq 46 \\
{[15]}\end{array}$ & Ln,w $=58(-7)$ & & $\begin{array}{c}\text { Simülasyon } \\
\text { sonuçlarına } \\
\text { göre } \\
\text { UYGUN } \\
\text { DEĞiL }\end{array}$ & $\begin{array}{c}\text { Mevcut duruma } \\
2,6 m m \text { kurşun } \\
\text { katkılı vinil ilavesi } \\
\text { ile; } \\
\text { Rw = 62 (-1; -5) } \\
\text { Ln,w = 43 (-1) } \\
\text { UYGUN olacaktır. }\end{array}$ \\
\hline \multirow{2}{*}{ 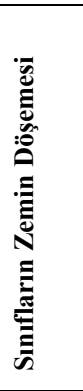 } & \multirow{2}{*}{$\begin{array}{l}\text { 2,6mm vinil } \\
\text { döşeme } \\
\text { kaplaması }+ \\
150 \mathrm{~mm} \\
\text { betonarme } \\
\text { döşeme+ } \\
250 \mathrm{~mm} \text { boşluk } \\
+ \text { Z profil } \\
\text { taşıyıc1 }+16 \mathrm{~mm} \\
\text { delikli taşyünü } \\
\text { asma tavan }\end{array}$} & \multirow[b]{2}{*}{ 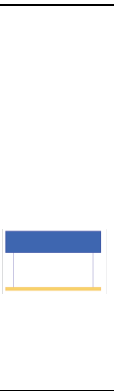 } & $\begin{array}{c}\mathrm{Rw} \\
{[15]}\end{array}$ & $R w=62(-2 ;-5)$ & \multirow[b]{2}{*}{ - } & $\begin{array}{c}\text { Simülasyon } \\
\text { sonuçlarına } \\
\text { göre } \\
\text { UYGUN } \\
\end{array}$ & - \\
\hline & & & $\begin{array}{c}\mathrm{Ln}, \mathrm{w} \leq 46 \\
{[15]}\end{array}$ & Ln,w = $59(-5)$ & & $\begin{array}{c}\text { Simülasyon } \\
\text { sonuçlarına } \\
\text { göre } \\
\text { UYGUN } \\
\text { DEĞIL }\end{array}$ & $\begin{array}{c}\text { Mevcut duruma } \\
\text { 2,6mm kurşun } \\
\text { katkıl vinil + } \\
\text { kauçuk yalıtım } \\
\text { ilavesi ile; } \\
\text { Rw = 71 (-2; -6) } \\
\text { Ln,w = 39 (1) } \\
\text { UYGUN olacaktır. }\end{array}$ \\
\hline 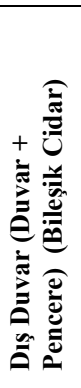 & $\begin{array}{l}60 \mathrm{~mm} \text { taş } \\
\text { kaplama }+ \\
190 \mathrm{~mm} \text { tuğla } \\
\text { duvar }+50 \mathrm{~mm} \\
\text { camyünü }+ \\
190 \mathrm{~mm} \text { tuğla } \\
\text { duvar }+25 \mathrm{~mm} \\
\text { siva }+(4 \mathrm{~mm} \\
\text { cam }+150 \mathrm{~mm} \\
\text { boşluk }+4 \mathrm{~mm} \\
\text { cam })\end{array}$ & & $\begin{array}{c}\text { Rw } \geq 55 \\
{[15]} \\
\\
\text { Çevresel } \\
\text { gürültü } \\
\text { düzeyi } \\
\text { 55dBA'ya } \\
\text { kadar olan } \\
\text { yerlerde } \\
\text { diş duvar } \\
\text { Rw,res } \geq \\
\text { 30 dB }[15]\end{array}$ & $\begin{array}{c}\text { Duvar için } \\
\text { Rw=64 (-1;-5) } \\
\text { Pencere için } \\
\text { Rw=45 (-1;-6) } \\
\text { Bileşik cidar } \\
\text { Rw,res=50 } \\
\text { (-2;-6) }\end{array}$ & - & $\begin{array}{c}\text { Simülasyon } \\
\text { sonuçlarına } \\
\text { göre UYGUN }\end{array}$ & e \\
\hline
\end{tabular}




\section{SONUÇ VE ÖNERILER (RESULTS AND SUGGESTIONS)}

Bu çalışmada, Ankara'nın tarihi binalarından Musiki Muallim Mektebi Mamak Belediyesi Konservatuvar binasının müzik işlevli sınıflarının gürültü kontrolüne yönelik analizi yapılmıştır. Bu bağlamda öncelikli olarak Insul 6.4 simülasyon programiyla sinıfları çevreleyen yapı elemanlarının ses yalıtım performansları ortaya konmuş, ardından gürültü kontrol ölçümleri yapılarak, simülasyon ve ölçüm sonuçları literatür bilgileri ile karşılaştırılmıştır. Elde edilen bulgular doğrultusunda ise aşağıdaki sonuçlara ulaşılmıştır:

Ankara Musiki Muallim Mektebi'nin sınıf mekânlarında; iki sınıf arasındaki iç duvarın ses azaltma indeksi değeri; yapılan ölçümler aracılığı ile $51(0 ;-2) \mathrm{dB}$, sınıf ve koridor arasındaki duvardaki ses azaltma indeksi değeri ise $28(-1 ;-1) \mathrm{dB}$ olarak hesaplanmıştır. $\mathrm{Bu}$ değerler; literatürde belirtilen uygun sınırlar içinde değildir (Tablo 4). Sinıf ve koridor arasındaki duvarda yer alan kapının ses yalıtım performansının düşük olması, bileşik cidarın ses azaltma indeksinin düşmesine neden olmaktadır. Kapının ses yalıtım performansının iyileştirilmesiyle iç duvarın (bileşik cidarın) ses azaltma indeksi de yükselecektir. Bunun için; kapıların ses yalıtım performansları arttırılmalı, kasa-kanat birleşimlerinde conta, kanat-döşeme birleşimlerinde keçe vb. yalıtım malzemeleri kullanılarak kap1 birleşim yerlerindeki açıklıkların giderilmesi gerekmektedir. Yapılmış olan tadilatlardan dolayı iki sınıf arasındaki iç duvarda açıklıklar meydana gelmiştir. $\mathrm{Bu}$ açıklıklar kapatılarak iç duvarın ses azaltma indeksi uygun sinırlara getirilebilecektir.

Zemin kat taban ve tavan döşemesi havada yayılan sese karşı yalıtım performansını sağlarken, katılarda yayılan sese karşı yeterli performansı sağlayamamıştır. Zemin kat döşemesinin iyileştirilmesi için 2,6 mm vinil döşeme kaplaması üstüne 2,6 mm kurşun katkılı vinil kaplama ilave edilmesi halinde zemin kat döşemesinin ses azaltma indeksi aynı kalacak [Rw; $62(-1 ;-5) \mathrm{dB}]$ ve darbe kaynaklı ses basıncı seviyesi [Ln,w; 43 (-1) dB] ile uygun değerlere getirilebilecektir. Tavan döşemesinin iyileştirilmesi için 2,6 mm vinil döşeme kaplaması üstüne 2,6 mm kurşun katkılı vinil kaplama ilave edilmesi ve kauçuk yalıtımlı taşıyıcı eleman kullanılması halinde tavan döşemesinin ses azaltma indeksi [Rw; $71(-2 ;-6) \mathrm{dB}]$ ve darbe kaynaklı ses basıncı seviyesi [Ln,w; 39 (1) dB] ile uygun değerlere ulaşılabilecektir (Tablo 4).

Pencereli diş duvar bileşeninde (bileşik cidarda); birleşik (muntabık) pencere kasalarının halen bulunması nedeniyle binanın orjinalinde çift cam uygulamasının yapılmış olduğu, ancak restorasyon sırasında ya da daha sonrasında çift cam uygulamasının kaldırılmış olduğu düşünülmektedir.
Her ne kadar diş duvar bileşeni için ses azaltma indeksi simülasyon sonuçları uygun sınırlar içinde kalmış olsa da, çift cam uygulamasına tekrar geçilmesinin yararlı olacağı düşünülmektedir.

\section{KISALTMALAR VE SEMBOLLER (ABBREVIATIONS AND SYMBOLS)}

C Orta ve yüksek frekanslı gürültü kaynağı için spektrum adaptasyon terimi

Ctr Düşük ve orta frekanslı gürültü kaynağı için spektrum adaptasyon terimi

dB Desibel - Ses basınç seviyesi birimi

dBA A-Ağırlıklı ses basınç seviyesi birimi

Hz Hertz

Leq Eşdeğer sürekli ses basınç seviyesi

Ln,w Darbe kaynaklı ses basınç seviyesi

MKM Mamak Kültür Merkezi

NC Gürültü düzeyi kriteri

Rw Ses azaltma indeksi

Rw,res Ses azaltma indeksi (dış yapı bileşeni için)

SEL Ses etkilenim seviyesi

STI Konuşmanın iletim indeksi

T Reverberasyon süresi

Tmid Reverberasyon süresi (500-1000 Hz için)

\section{TEŞEKKÜR (ACKNOWLEDGEMENTS)}

Bu çalışma; 2009/2011-43 kodlu Gazi Üniversitesi Bilimsel Araştırma Projesi'nin bir bölümü olup, Gazi Üniversitesi tarafından desteklenmiştir.

\section{KAYNAKLAR (REFERENCES)}

1. Yılmaz Demirkale, S., Çevre ve yapı akustiği, Birsen Yayınevi, İstanbul, 2007.

2. Kurra, S., "Çevre gürültüsü kirliliği ve kontrolü", Gürültü ile Savașım Sempozyumu,YTÜ, İstanbul, 31-40, 5 Haziran 1997.

3. Kurra, S., Çevre gürültüsü ve yönetimi I-II-III, Bahçeşehir Üniversitesi Yayınları, İstanbul,2009.

4. Özçetin, Z., Konservatuvar Binalarının Gürültü Kontrolü Açısından Analizi ve Bir Örnek Çalışma: Ankara Musiki Muallim Mektebi Mamak Belediyesi Konservatuvar Binası, Yüksek Lisans Tezi, Gazi Üniversitesi, Fen Bilimleri Enstitüsü, 2011.

5. Demirel, F., Özçetin, Z., Doğan, M., Mevzuatlar Cerçevesinde Konservatuvar Binalarının Gürültü Kontrolü Açısından Analizi ve Bir Örnek Çalışma: Ankara Musiki Muallim Mektebi Mamak Belediyesi Konservatuvar Binası, Gazi Üniversitesi,Fen Bilimleri Enstitüsü Bilimsel Araştırma Projesi raporu, 2011.

6. Özçetin, Z., Demirel, F., "Gürültü Kontrolüne Yönelik Mevzuatların Konservatuvar BinalarıAçısından İncelenmesi”, Beykent Üniversitesi Fen Bilimleri Enstitüsü Fen ve Mühendislik Bilimleri Dergisi ISSN:1307-3818, Cilt 5, No 1-2, 145-154, 2012. 
7. Aslanoğlu, İ., Musiki Muallim Mektebi, Mimarlık, 2004.

8. Cavanaugh, W.J., Wilkes, J.W., Architectural acoustics principles and practice, John Wiley\& Sons, Inc, New York, 1999.

9. Egan, D., Architectural acoustics, Mc Graw Hill, New York, 2007.

10. Mehta, M., Johnson, J., Rocafort, J., Architectural acoustics principles and design, Prentice-Hall, New Jersey, 1999.

11. Building Bulletin 93, Acoustic design of schools a design guide, Department for Education and Skills The Stationary Office, London, 2003.

12. Mumovic, D., Palmer, J., Davies, M., Orme, M., Ridley, I., ve ark., "Winter indoor air quality, thermal comfort and acoustic performance of newly built secondary schools in England", Building and Environment, 44,1466-1477, 2009.

13. ANSI S12.60-2002, Acoustical performance criteria, design requirements, and guidelinesfor schools, American National Standard, MelvilleABD, 2002.

14. Mommertz, E., Acoustics and Sound Insulation, Detail Practice, Berlin, 2009.
15. DIN 4109, Sound insulation in buildings, Almanya, 1989.

16. Zannin, P.H.T., Zwirtes, D.P.Z., "Evaluation of the acoustic performance of classroms in publicschools", Applied Acoustics, 70, 626-635, 2009.

17.Zannin, P.H.T., Marcon, C.R., "Objective and subjective evaluation of the acoustic comfort inclassrooms", Applied Ergonomics, 38, 675680, 2007.

18. TS ISO 1996-2: 2009, “Akustik-Çevre Gürültüsünün Tarifi, Ölçülmesi ve Değerlendirilmesi-Bölüm 2: Çevre Gürültü Seviyelerinin Tayini", 2009.

19. TS EN ISO 16283-1: 2014, “Akustik-Yap1 Elemanlarında ve yapılarda ses yalıtımının alan ölçümü-Bölüm 1: Hava ile yayılan sesin yalıtımı (ISO 16283-1:2014)" 2014.

20. TS EN ISO 717-1: 2013, “Akustik-Yapılarda ve yap1 elemanlarında ses yalıtımının değerlendirilmesi-Bölüm 1: Hava ile yayılan sesin yalıtımı (ISO 717-1: 2013)", 2013.

\section{EKLER}

Ek-1. Çevresel Gürültü Düzeyi Ölçüm Sonuçları (Environmental Noise Level Measurement Results)

\begin{tabular}{|cccc|}
\hline Frekans $(\mathbf{H z})$ & Alıcı 1 noktası & Ortalama gürülttï düzeyleri - dB & Alıcı $\mathbf{2}$ noktası \\
\hline $\mathbf{6 3}$ & 60,3 & 61,0 & Alıcı 3 noktası \\
\hline $\mathbf{1 2 5}$ & 60,0 & 62,2 & 59,8 \\
\hline $\mathbf{2 5 0}$ & 56,0 & 56,8 & 61,0 \\
\hline $\mathbf{5 0 0}$ & 51,1 & 52,8 & 58,0 \\
\hline $\mathbf{1 0 0 0}$ & 50,1 & 50,6 & 52,0 \\
\hline $\mathbf{2 0 0 0}$ & 45,5 & 46,0 & 51,5 \\
\hline $\mathbf{4 0 0 0}$ & 36,3 & 37,2 & 50,0 \\
\hline $\mathbf{8 0 0 0}$ & $<30$ & $<30$ & 35,8 \\
\hline
\end{tabular}

Ek-2. Arka Plan Gürültü Düzeyi Ölçüm Sonuçları (Background Noise Level Measurement Results)

\begin{tabular}{|c|c|c|c|c|c|c|c|}
\hline \multirow{2}{*}{$\begin{array}{l}\text { Frekans } \\
(\mathrm{Hz})\end{array}$} & \multicolumn{7}{|c|}{ Ortalama gürültüi düzeyleri - $\left(\mathrm{L}_{\mathrm{eq}}\right) \mathrm{dBA}$} \\
\hline & A1 noktası & A2 noktası & A3 noktası & A4 noktası & A5 noktası & A6 noktasi & Ortalama \\
\hline 100 & 42,1 & 40,4 & 42,5 & 41,1 & 43,7 & 41,6 & 41,9 \\
\hline 125 & 40,1 & 40,3 & 42,5 & 43,7 & 39,1 & 42,6 & 41,3 \\
\hline 160 & 36,4 & 37,4 & 38,8 & 41,1 & 36,4 & 39,5 & 38,2 \\
\hline 200 & 31,4 & 33,3 & 33,5 & 34,7 & 31,9 & 34,8 & 33,2 \\
\hline 250 & 28,7 & 28,7 & 29,7 & 31,7 & 28,3 & 31,3 & 29,7 \\
\hline 315 & 27,2 & 27,8 & 28,4 & 29,3 & 27,0 & 27,9 & 27,9 \\
\hline 400 & 26,5 & 24,3 & 25,7 & 26,1 & 24,3 & 25,1 & 25,3 \\
\hline 500 & 26,6 & 23,9 & 24,1 & 24,2 & 23,0 & 23,5 & 24,2 \\
\hline 630 & 25,3 & 24,5 & 23,4 & 23,2 & 22,2 & 24,3 & 26,6 \\
\hline 800 & 24,6 & 27,5 & 22,8 & 23,0 & 24,2 & 22,9 & 24,1 \\
\hline 1000 & 24,0 & 26,6 & 21,9 & 22,2 & 20,3 & 20,8 & 22,6 \\
\hline 1250 & 20,4 & 24,8 & 20,7 & 20,6 & 19,2 & 20,9 & 21,1 \\
\hline 1600 & 20,2 & 21,6 & 20,6 & 20,3 & 19,4 & 19,9 & 20,3 \\
\hline 2000 & 20,8 & 23,5 & 21,6 & 20,8 & 20,8 & 20,5 & 21,3 \\
\hline 2500 & 21,8 & 23,7 & 22,3 & 22,0 & 21,7 & 21,7 & 22,2 \\
\hline 3150 & 24,1 & 24,4 & 22,5 & 23,1 & 23,8 & 22,5 & 23,4 \\
\hline 4000 & 26,7 & 25,8 & 21,7 & 22,7 & 25,3 & 22,0 & 24,0 \\
\hline 5000 & 19,8 & 21,6 & 20,2 & 19,4 & 19,2 & 19,1 & 19,8 \\
\hline 6300 & 18,6 & 20,6 & 18,8 & 18,1 & 17,9 & 18,0 & 18,6 \\
\hline 8000 & 17,0 & 20,1 & 17,1 & 16,2 & 16,4 & 16,2 & 17,1 \\
\hline Toplam & 25,7 & 26,6 & 25,5 & 25,9 & 24,6 & 25,4 & 25,7 \\
\hline
\end{tabular}


Ek-3. İki Sınıf Arasındaki İç Duvar için Ses Azaltma İndeksi Sonuçları (Sound Reduction İndex Results for the Inner Wall Between Two Classrooms)

\begin{tabular}{|c|c|c|c|c|c|c|c|c|c|}
\hline \multirow{2}{*}{$\begin{array}{l}\text { Frekans } \\
(\mathrm{Hz})\end{array}$} & \multicolumn{2}{|c|}{$\mathrm{L}_{1}(\mathrm{~dB})$} & \multicolumn{2}{|c|}{$\mathrm{L}_{2}(\mathrm{~dB})$} & \multicolumn{3}{|c|}{$\mathrm{L}_{1}-\mathrm{L}_{2}(\mathrm{~dB})$} & \multirow{2}{*}{$\begin{array}{l}\text { Ort. } L_{1}-L_{2} \\
\quad(d B)\end{array}$} & \multirow[t]{2}{*}{ Rw (dB) } \\
\hline & A8 & A9 & A6 & A12 & A8-A6 & А9-A6 & A9-A12 & & \\
\hline 100 & 102,7 & 94,8 & 59,5 & 57,1 & 43,2 & 35,3 & 45,6 & 41,3 & 41,5 \\
\hline 125 & 101,0 & 102,3 & 62,6 & 63,4 & 38,4 & 39,7 & 37,6 & 38,5 & 38,2 \\
\hline 160 & 107,3 & 103,9 & 63,1 & 61,9 & 44,2 & 40,8 & 45,4 & 43,4 & 43,4 \\
\hline 200 & 105,3 & 104,0 & 58,2 & 61,1 & 47,1 & 45,8 & 44,2 & 45,7 & 44,9 \\
\hline 250 & 103,0 & 101,7 & 57,1 & 56,5 & 45,9 & 44,6 & 46,5 & 45,6 & 44,8 \\
\hline 315 & 100,6 & 98,3 & 56,5 & 52,3 & 44,1 & 41,8 & 48,3 & 44,7 & 43,2 \\
\hline 400 & 102,5 & 100,1 & 50,3 & 50,8 & 52,2 & 49,8 & 51,7 & 51,2 & 49,4 \\
\hline 500 & 99,1 & 98,6 & 46,9 & 47,1 & 52,2 & 51,7 & 52,0 & 51,9 & 50,0 \\
\hline 630 & 96,5 & 95,9 & 42,2 & 41,9 & 54,3 & 53,7 & 54,6 & 54,2 & 52,0 \\
\hline 800 & 96,0 & 95,1 & 40,2 & 39,9 & 55,8 & 54,9 & 56,1 & 55,6 & 53,1 \\
\hline 1000 & 94,6 & 93,8 & 39,0 & 37,8 & 55,6 & 54,8 & 56,8 & 55,7 & 52,8 \\
\hline 1250 & 96,1 & 94,6 & 38,2 & 37,5 & 57,9 & 56,4 & 58,6 & 57,6 & 54,4 \\
\hline 1600 & 97,3 & 96,3 & 41,1 & 41,5 & 56,2 & 55,2 & 55,8 & 55,7 & 52,8 \\
\hline 2000 & 95,6 & 92,2 & 41,1 & 39,7 & 54,5 & 51,1 & 55,9 & 53,8 & 50,6 \\
\hline 2500 & 95,4 & 93,9 & 42,6 & 41,8 & 52,8 & 51,3 & 53,6 & 52,5 & 49,2 \\
\hline 3150 & 95,0 & 92,8 & 42,0 & 41,2 & 53.0 & 50,8 & 53,8 & 52,5 & 49,3 \\
\hline 4000 & 91,9 & 92,3 & 37,7 & 36,9 & 54,2 & 54,6 & 55,0 & 54,6 & 51,2 \\
\hline 5000 & 94,7 & 94,1 & 35,9 & 36,1 & 58,8 & 58,2 & 58,6 & 58,5 & 54,8 \\
\hline 6300 & 91,5 & 92,4 & $*$ & $*$ & - & - & - & - & - \\
\hline 8000 & 83,8 & 84,1 & $*$ & $*$ & - & - & - & - & - \\
\hline
\end{tabular}

Ek-4. Sınıf ile Koridor Arasındaki İç Duvar için Ses Azaltma İndeksi Sonuçları (Sound Reduction İndex

\begin{tabular}{|c|c|c|c|c|c|c|c|}
\hline \multirow{2}{*}{$\begin{array}{l}\text { Frekans } \\
(\mathrm{Hz})\end{array}$} & \multirow{2}{*}{$\begin{array}{c}\mathrm{L}_{1}(\mathrm{~dB}) \\
\mathbf{A 1 0}\end{array}$} & \multicolumn{2}{|c|}{$\mathrm{L}_{2}(\mathrm{~dB})$} & \multicolumn{2}{|c|}{$\mathrm{L}_{1}-\mathrm{L}_{2}(\mathrm{~dB})$} & \multirow{2}{*}{$\begin{array}{l}\text { Ort. } \mathrm{L}_{1}-\mathrm{L}_{2} \\
\quad(\mathrm{~dB})\end{array}$} & \multirow[t]{2}{*}{ Rw (dB) } \\
\hline & & A1 & A4 & A10-A1 & A10-A4 & & \\
\hline 100 & 99,9 & 73,7 & 74,8 & 26,2 & 25,1 & 25,6 & 23,2 \\
\hline 125 & 108,0 & 82,9 & 82,9 & 25,1 & 25,1 & 25,1 & 22,7 \\
\hline 160 & 109,5 & 79,9 & 82,0 & 29,6 & 27,5 & 28,5 & 26,1 \\
\hline 200 & 107,2 & 83,3 & 82,5 & 23,9 & 24,7 & 24,3 & 21,9 \\
\hline 250 & 109,4 & 78,4 & 78,8 & 31,0 & 30,6 & 30,8 & 28,4 \\
\hline 315 & 102,9 & 76,8 & 77,3 & 26,1 & 25,6 & 25,8 & 23,4 \\
\hline 400 & 105,4 & 75,9 & 74,6 & 29,5 & 30,8 & 30,1 & 27,7 \\
\hline 500 & 102,6 & 70,6 & 73,4 & 32,0 & 29,2 & 30,6 & 28,2 \\
\hline 630 & 100,5 & 68,3 & 69,1 & 32,2 & 31,4 & 31,8 & 29,4 \\
\hline 800 & 99,3 & 66,5 & 66,2 & 32,8 & 33,1 & 32,9 & 30,5 \\
\hline 1000 & 98,2 & 66,8 & 65,5 & 31,4 & 32,7 & 32,0 & 29,6 \\
\hline 1250 & 99,9 & 66,8 & 66,7 & 33,1 & 33,2 & 33,1 & 30,7 \\
\hline 1600 & 99,8 & 72,1 & 71,1 & 27,7 & 28,7 & 28,2 & 25,8 \\
\hline 2000 & 98,4 & 71,0 & 70,1 & 27,4 & 28,3 & 27,8 & 25,3 \\
\hline 2500 & 99,5 & 71,8 & 70,8 & 27,7 & 28,7 & 28,2 & 25,8 \\
\hline 3150 & 98,3 & 69,6 & 69,3 & 28,7 & 29,0 & 28,8 & 26,4 \\
\hline 4000 & 96,7 & 67,4 & 66,4 & 29,3 & 30,3 & 29,8 & 27,3 \\
\hline 5000 & 97,6 & 65,4 & 64,7 & 32,2 & 32,9 & 32,5 & 30,1 \\
\hline 6300 & 96,1 & 60,7 & 59,8 & 35,4 & 36,3 & 35,8 & 33,4 \\
\hline 8000 & 87,0 & 50,8 & 50,3 & 36,2 & 36,7 & 36,4 & 33,9 \\
\hline
\end{tabular}


